Rev. Int. Contam. Ambie. 36 (1) 81-95, 2020

DOI: $10.20937 /$ RICA.2020.36.53276

\title{
EFFECT OF INOCULUM SOURCE ON THE ANAEROBIC DIGESTION OF MEZCAL VINASSES AT DIFFERENT SUBSTRATE-INOCULUM RATIOS
}

Efecto de la fuente de inóculo en la digestión anaerobia de vinazas de mezcal a diferentes proporciones sustrato-inóculo

\author{
Mónica LÓPEZ VELARDE SANTOS ${ }^{1 *}$, Eusebio VENTURA RAMOS Jr. ${ }^{2}$, \\ José Alberto RODRÍGUEZ MORALES ${ }^{2}$ and Hensel OLIVER ${ }^{1}$
}

\author{
${ }^{1}$ University of Kassel, Nordbahnhofstraße 1A, 37213 Witzenhausen, Germany \\ ${ }^{2}$ Universidad Autónoma de Querétaro, Centro Universitario, Cerro de las Campanas s/n, 76010 Santiago de \\ Querétaro, Querétaro, México \\ *Corresponding author: mlopezvelarde@uni-kassel.de
}

(Received May 2018; accepted March 2019)

Key words: anaerobic sludge, biogas, cattle manure, kinetic modeling, methane, organic matter removal, SI ratio

\begin{abstract}
Vinasses are a very harmful residue for the environment if no treatment takes place before their discharge. The present study focuses on the anaerobic digestion (AD) of mezcal vinasses for treatment and energy generation. The effect of two inoculum sources, anaerobic sludge and cattle manure, were assessed by biochemical methane potential assays (BMP), testing different substrate to inoculum ratios (SI-ratios). Mathematical modeling was performed using three sigmoidal bacterial growth curves (Gompertz, transference and logistic), in order to understand the kinetics of methane production. Anaerobic sludge was digested with vinasses at SI-ratios of $0.1,0.3$ and 0.4 and cattle manure at $0.3,0.5$ and 0.7 . When using a 0.3 SI-ratio, the digestion of vinasses with manure showed the highest results regarding biogas (1025.44 \pm 33.80 $\mathrm{L} / \mathrm{kgVS}$ ), methane (up to $81 \%$ ) and organic matter removal (54\% volatile solids removal). Manure indicated a higher specific methane yield growth, with a longer lag phase. Concentrations containing low vinasses content resulted in an inefficient AD due to the lack of organic matter, whilst concentrations with high vinasses content resulted in $\mathrm{AD}$ inhibition. The present work shows that cattle manure is an alternative inoculum source to achieve a more efficient anaerobic digestion. The optimal SI-ratio to be used for the digestion of vinasses is 0.3 , at which the bacterial population has enough substrate to work efficiently.
\end{abstract}

Palabras clave: lodo anaerobio, biogás, estiércol de vaca, modelo cinético, metano, remoción de materia orgánica, proporción SI

\section{RESUMEN}

Las vinazas son un residuo dañino para el medio ambiente si no se lleva a cabo un tratamiento previo a su descarga. En el presente trabajo se estudia la digestión anaerobia de vinazas de la producción de mezcal para tratamiento y generación de energía. El efecto de dos fuentes de inóculo, lodo anaerobio y estiércol de vaca se analizó por medio de pruebas bioquímicas de potencial de metano a distintas proporciones sustrato-inóculo (SI). La modelación matemática se hizo mediante tres curvas sigmoideas de crecimiento bacteriano (Gompertz, transferencia y logístico), para entender la 
cinética de la producción de metano. El lodo anaerobio se digirió con vinazas en las proporciones SI $0.1,0.3$ y 0.4 , y el estiércol en $0.3,0.5$ y 0.7 . Al digerir la proporción SI 0.3, la digestión con estiércol mostró los mejores resultados para biogás (1025.44 $\pm 33.80 \mathrm{~L} / \mathrm{kgVS}$ ), metano (hasta $81 \%$ ) y eliminación de materia orgánica (54\% de remoción de sólidos volátiles). El estiércol demostró mayor velocidad específica de producción de metano, con una fase de adaptación más larga. Las concentraciones con menos vinazas mostraron una digestión anaerobia ineficiente por la falta de materia orgánica, mientras que las concentraciones con más vinazas mostraron inhibición. Este trabajo muestra que el estiércol es un inóculo alternativo para mejorar la eficiencia de digestión anaerobia, en comparación con el lodo usado convencionalmente. La mejor proporción SI fue de 0.3 , por medio de la cual la población bacteriana tuvo suficiente sustrato para trabajar de manera eficiente.

\section{INTRODUCTION}

Vinasses are a very aggressive residue from the distillation of alcoholic beverages, due to their high organic matter content $(35000-50000 \mathrm{mg} / \mathrm{L}$ as biochemical oxygen demand [BOD] and $100000-150$ $000 \mathrm{mg} / \mathrm{L}$ as chemical oxygen demand [COD]), high discharging temperature and low $\mathrm{pH}$ value. If no treatment takes place before its discharge, water and soils could be negatively affected causing eutrophication and crop contamination (Robles-González et al. 2012). In recent years, anaerobic digestion (AD) has been a popular method for the simultaneous treatment of the recalcitrant content of vinasses and bioenergy production. A key point for an efficient $\mathrm{AD}$ treatment is the understanding of the biological processes in a bioreactor.

\section{Anaerobic digestion}

Biogas is produced during $\mathrm{AD}$. In principle, every organic material can be digested; however, not all organic material components can be degraded by the same bacterial strains at the same rate. According to the bacterial group contained in the inoculum, bacteria degrade substrate and multiply at different rates. The generation time of each one describes the capability to duplicate in cell number and accelerate its degradation speed. Methanogens have a slower generation time than hydrolytic and acidogenic bacteria. The generation time of the hydrolytic and acidogenic bacteria are about 24-36 h, acetogenic bacteria 40-132 $\mathrm{h}$ and methanogenic bacteria up to $240 \mathrm{~h}$ (KWS 2009).

One of the main targets of AD is to achieve a high methane content in biogas. Biochemical methane potential test (BMP) is a method to determine if the substrate is digested by AD (Strömberg et al. 2014). This test shows the substrate degradation rate, as well as the methane potential.

\section{Kinetic modeling of methane production}

Due to the similarity between bacterial growth curves (Fig. 1) and biogas/methane production curves (Fig. 2), authors suggest that AD curves obey a sigmoidal function (Altaş 2009, Syaichurrozi et al. 2013, Ware and Power 2017). Mathematical models of sigmoidal bacterial growth curves are normally used to evaluate the specific growth rate and lag phase of a microbial population. The lag phase is the first phase of bacterial growth, where adaptation takes place and bacteria increase only in size but not in number (Rolfe et al. 2012). The growth curves generated from the mathematical models describe bacterial growth over a period of time, until a saturation state. As shown in figure 1 (Zwietering et al. 1990), the specific bacterial growth begins at zero with a slow gas production and accelerates to a maximum growth rate $(\mu \mathrm{m})$ in a specific time (lag phase $\lambda$ ). It continues with a rapid gas production (exponential phase) and ends when the curve reaches a final phase at which the growth rate diminishes

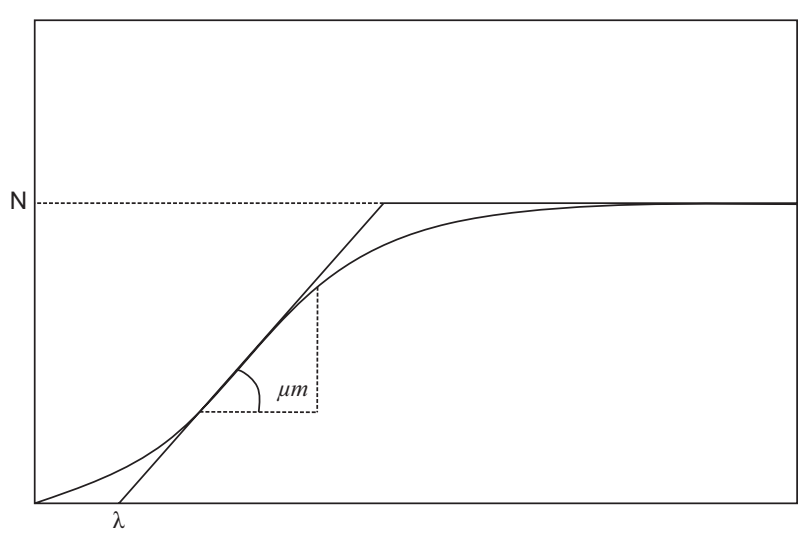

Fig. 1. Bacterial growth curve (Wave and Power 2017) 


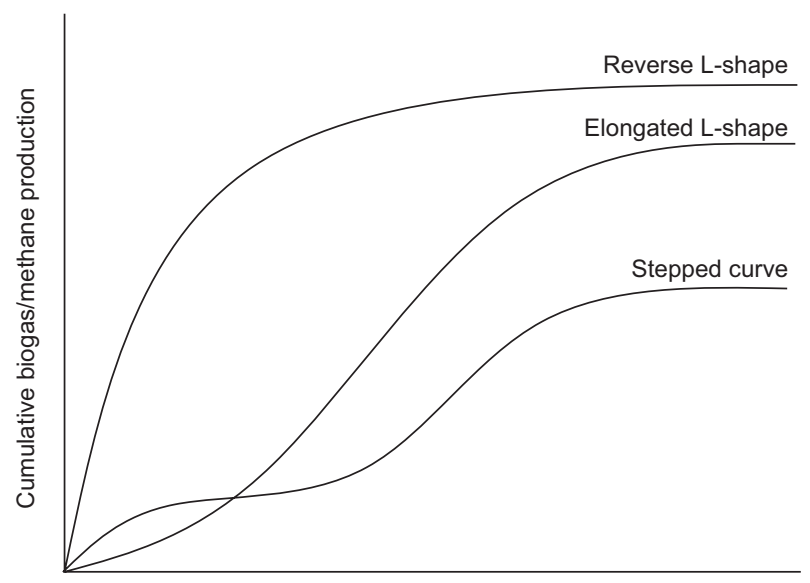

Fig. 2. Typical cumulative biogas and methane production curves (VDI 2016, Ware and Power 2017)

(asymptote $N$ ) up to zero, called point of saturation or stationary phase. When the lag phase takes place, hydrolytic bacteria degrade protein, carbohydrates and fat into aminoacids, sugar and fatty acids. Once the biomass is available for the acidogenic, acetogenic and methanogenic bacteria, the exponential phase takes place. At this point organic fatty acids, hydrogen and carbon dioxide form methane. At the end, the nondegradable compounds of biomass remain and the stationary phase is reached (Friehe et al. 2013, Ware and Power 2017).

In the present study, three sigmoidal bacterial growth curve equations (Gompertz model, logistic model and transference function) were used to determine the kinetics of vinasses methane production. When fitting the sigmoidal functions of the cumulative methane yield curves generated from BMP assays to the mathematical models, AD performance can be evaluated. The maximum methane production potential ( $N$ or $y$-axis intercept of highest curve point), the maximum specific methane yield growth rate ( $\mu \mathrm{m}$ or slope of the exponential phase) and the lag phase ( $\lambda$ or $x$-axis intercept of slope) can be determined. Some of these models were modified by Zwietering et al. (1990), so that the parameters have a biological meaning, rather than mathematical. Therefore, a better understanding of the microbiological processes can be achieved.

\section{Effect of inoculum on anaerobic digestion}

To achieve an efficient conversion to biogas and methane, the inoculum used for AD should contain a high concentration of active microbial communities. The source of inoculum plays a crucial role, especially when digesting complex substrates with high organic content (Hidalgo and Martín-Marroquín 2014). The inoculum source affects the decomposition rate of macromolecules such as proteins, fats and carbohydrates. The use of an adequate inoculum increases the substrate degradation rate, and enhances the enzymatic activity, as well as the process stability.

Since AD was subject of research during the last century, substrate and operation parameters played an important role for efficient biogas generation. The source of the inoculum itself was though not studied deeply until recent years ( $\mathrm{Gu}$ et al. 2014). Córdoba et al. (2015) compared in batch experiments at mesophilic temperature, the methane production of swine wastewater using rumen, stabilized swine wastewater and sewage sludge, as inocula. Sewage sludge achieved not only the highest methane production $\left(250 \mathrm{~L}_{\mathrm{CH} 4} / \mathrm{kgVS}\right)$ but also the highest organic matter removal (near to $50 \%$ ) in terms of volatile solids (VS) and chemical oxygen demand (COD). Facchin et al. (2012) tested the biogas production of food waste using two different inoculum sources in batch assays at mesophilic temperature. Inocula were obtained from a reactor digesting waste-activated sludge-food waste and only food waste. The biogas production using only food waste as inoculum was $760 \mathrm{~L} / \mathrm{kgVS}$ with $57 \%$ methane, whereas the mixture of waste-activated sludge-food waste resulted in $10 \%$ more methane production. Gu et al. (2014) evaluated the effect of different inoculum sources on rice straw AD. Digested manure, digester swine manure, digested chicken manure, municipal sludge, anaerobic granular sludge and paper mill sludge were compared. It was found that digested manures were more effective than sludge, regarding biogas production and lignocellulose degradation. The reactors inoculated with digested manure achieved the highest biogas yield (325.3 L/kgVS). Vinasses AD of tequila/mezcal production has been studied and reported by some authors, nevertheless the inoculum source used in $\mathrm{AD}$ is mostly harvested from brewery wastewater treatment. Methan yields of 210 up to $322 \mathrm{~L}_{\mathrm{CH} 4} / \mathrm{kg}$ $\mathrm{COD}_{\text {removed }}$ has beed reported (Espinoza-Escalante et al. 2008, Méndez-Acosta et al. 2010, Buitrón et al. 2014, Jáuregui-Jáuregui et al. 2014).

\section{Effect of substrate-inoculum rate on anaerobic digestion}

To prevent AD inhibition, the proportion of substrate should not exceed the proportion of inoculum. According to the VDI-4630 (VDI 2016), the substrate to inoculum ratio (SI-ratio) should not exceed 0.5 in terms of VS (equation 1), 
$\frac{\text { VS Substrate }}{\text { VS Inoculum }} \leq 0.5$

Fagbohungbe et al. (2015) analyzed the SI-ratio effect on AD of human faeces. The SI-ratio 0.5 showed the highest methane production $\left(254.4 \mathrm{~L}_{\mathrm{CH} 4} /\right.$ $\mathrm{kgVS}$ ) and highest pathogen removal, while SI-ratio 0.4 showed the lowest methane yield $\left(110 \mathrm{~L}_{\mathrm{CH}} 4\right.$ $\mathrm{kgVS}$ ) and lowest pathogen removal. Slimane et al. (2014) found that the AD of slaughterhouse wastewater increased with SI-ratio 0.3, in comparison to SI-ratios 0.5 and 1 . After 48 days of experiments, SI-ratio 0.3 reached a biogas production of $864 \mathrm{~mL}$, SI-ratio 0.5 produced $856 \mathrm{~mL}$ and SI-ratio 1.0 generated $504 \mathrm{~mL}$ of biogas.

There is very little literature reported on the comparison of different inoculum sources for $\mathrm{AD}$ of vinasses from mezcal and tequila production, or the effect of using different SI-ratios. The aim of this study was to analyze in BMP assays the effect of two different inoculum sources. Inocula, anaerobic sludge and cattle manure were used and methane yield, as well as VS removal were compared. Different SIratios ranging from 0.1 to $0.7(0.1,0.3$ and 0.4 for sludge and 0.3, 0.5 and 0.7 for manure) were tested to determine the inoculum and vinasses ratio, which shows the highest efficiency of methane production, as well as organic matter removal.

\section{MATERIALS AND METHODS}

\section{Substrate and inoculum}

Vinasses generated from cooking, fermentation and distillation of Agave salmiana to mezcal were used as substrate. Two different inocula were tested for $\mathrm{AD}$. The first inoculum used was anaerobic sludge collected from a sequencing batch reactor (SBR) for wastewater treatment in the Engineering Faculty at the Autonomous University of Queretaro. The second inoculum used was filtered cattle manure collected from local pasture-raised dairy. Tables I and II show the vinasses and inocula characteristics measured prior to BMP assays. Inocula and substrate were collected, transported and refrigerated at $4{ }^{\circ} \mathrm{C}$ prior to use.

\section{Anaerobic digestion tests}

BMP assays were carried out in batch tests using $250 \mathrm{~mL}$ Erlenmeyer's flasks at mesophilic temperatures, according to the German standard method VDI-4630 (VDI 2016). In the first assays, anaerobic sludge was tested as inoculum at SI-ratios $0.1,0.3$ and 0.4 . In the second assays cattle manure was tested
TABLE I. CHARACTERISTICS OF VINASSES

\begin{tabular}{lc}
\hline Parameter & Value \\
\hline $\mathrm{pH} @ 27{ }^{\circ} \mathrm{C}$ & 4.77 \\
Chemical oxygen demand (g/L) & 59 \\
Total sugar content (g/L) & 51 \\
Total solids (\% of fresh mass) & 4.91 \\
Total solids (g/L) & 49.1 \\
Volatile solids $(\%$ of fresh mass) & 2.95 \\
Volatile solids (g/L) & 29.5 \\
Total dissolved solids $(\mathrm{g} / \mathrm{L})$ & 5.9 \\
Conductivity (mS/cm) & 11.76 \\
REDOX potential (mV) & -142 \\
Sulphate ion (g/L) & 1.04 \\
Phosphate ion (g/L) & 0.3 \\
Nitrate ion (g/L) & 0.48 \\
Total nitrogen $(\mathrm{g} / \mathrm{L})$ & 0.13 \\
Total phosphorous $(\mathrm{g} / \mathrm{L})$ & 0.02 \\
Turbidity (nephelometric turbidity units) & 55.4 \\
\hline
\end{tabular}

TABLE II. CHARACTERISTICS OF INOCULUM SOURCES

\begin{tabular}{lcr}
\hline Parameter & $\begin{array}{c}\text { Anaerobic } \\
\text { sludge }\end{array}$ & $\begin{array}{c}\text { Cattle } \\
\text { manure }\end{array}$ \\
\hline $\mathrm{pH} @ 27^{\circ} \mathrm{C}$ & 7.32 & 8.10 \\
Chemical oxygen demand (g/L) & 31.75 & 24.39 \\
Total solids (\% of fresh mass) & 3.19 & 5.31 \\
Total solids (g/L) & 33.19 & 53.10 \\
Volatile solids (\% of fresh mass) & 2.95 & 4.40 \\
Volatile solids (g/L) & 29.5 & 44.00 \\
Total dissolved solids (g/L) & 6.49 & 14.14 \\
Total nitrogen (g/L) & 0.33 & 1.50 \\
Conductivity (mS/cm) & 12.98 & 28.24 \\
REDOX potential (mV) & -313 & -352 \\
Volatile organic acids $(\mathrm{gHAc} / \mathrm{L})$ & 17.85 & 5.98 \\
Total inorganic carbon $(\mathrm{gCaCO} / \mathrm{L})$ & 19 & 20.50 \\
Volatile organic acids/total & & \\
inorganic carbon & 0.32 & 0.98 \\
\hline
\end{tabular}

as inoculum at SI-ratios $0.3,0.5$ and 0.7. SI-ratios were prepared according to equation 1 , considering the $\%$ VS in tables I and II. The experimental setup was carried out for 26 and 30 days, respectively. To evaluate microbial activity, inoculum digesting control tests were performed. Results were subtracted to the assays digesting vinasses and inoculum, in order not to confuse the $\mathrm{AD}$ of vinasses with the $\mathrm{AD}$ of inocula (VDI 2016).

\section{Determination of the methane yield}

The biogas quantity produced in $24 \mathrm{~h}$ was measured according to the water displacement principle. Grams of missing water were weighted daily and converted to liters of biogas, considering a biogas density of $1.2 \mathrm{~m}^{3} / \mathrm{kg}$ (Uni Bremen 2009). Biogas 
quality was measured with the gas analyzer Multitec 540 from Sewerin $\mathrm{GmbH}$. Methane $\left(\mathrm{CH}_{4}\right)$, carbon dioxide $\left(\mathrm{CO}_{2}\right)$, oxygen $\left(\mathrm{O}_{2}\right)$, carbon monoxide $(\mathrm{CO})$ and hydrogen sulfide $\left(\mathrm{H}_{2} \mathrm{~S}\right)$ were measured. The sensitivity ranges of the gas analyzer were:

- Test gas 100 vol.- $\% \mathrm{CH}_{4}$, display $95-105$ vol.-\%

- Test gas 100 vol.- $\% \mathrm{CO}_{2}$, display 95-105 vol.-\%

- Test gas 20,9 vol.- $\% \mathrm{O}_{2}$, display 20.4-21.4 vol.-\%

- Test gas $40 \mathrm{ppm} \mathrm{H}_{2} \mathrm{~S}$, display $30-50 \mathrm{ppm}$

- Test gas 40 ppm CO, display 37-43 ppm

Biogas production was daily quantified in terms of L/ $\mathrm{kg}$ VS initially added. Methane production was calculated based on the daily methane content (\%) in biogas. Methane yield of every assay was reported as the net volume of methane produced during the incubation period per VS contained at the beginning of the tests $\left(\mathrm{L}_{\mathrm{CH} 4} / \mathrm{kgVS}\right)$.

\section{Kinetic modeling}

The cumulative methane yield is plotted against the digestion time. The kinetics of methane production is determined by methanogenic bacteria performance and substrate characteristics. Figure 2 shows examples of typical cumulative biogas and methane yields. The evaluation of the BMP curves can be aided by mathematical models of methane production kinetics (El-Mashad 2013, Dong et al. 2016, Ware and Power 2017, Yangyang et al. 2018).

The regression analysis of non-linear leastsquares was performed using the software Statistica 13. The cumulative methane yield curves of BMP assays were fitted to the non-linear equations of the Gompertz model (equation 2), logistic model (equation 3 ) and transference function (equation 4$)$,

$M_{T}=N * \exp (-\exp ((\exp (1) *$

$\mu m) / N o *(\lambda-\mathrm{t})+1))$

$\left.M_{T}=N /(1+\exp ((4 * \mu m / N o) *(\lambda-\mathrm{t})+2))\right)$

$M_{T}=N *(1+\exp (-\mu m *(\lambda-\mathrm{t}) / N o))$

whereas $M_{\mathrm{T}}$ : cumulative methane production $\left(\mathrm{LCH}_{4} /\right.$ $\mathrm{kgVS}), N$ : maximum methane production potential ( $\left.\mathrm{L} \mathrm{CH}_{4} / \mathrm{kgVS}\right)$, No: start methane production $\left(\mathrm{L} \mathrm{CH}_{4} /\right.$ $\mathrm{kgVS}$ ), $\mu \mathrm{m}$ : maximum specific methane production growth rate $\left(\mathrm{L} \mathrm{CH}_{4} / \mathrm{kgVS}^{*} \mathrm{~d}\right), \lambda$ : lag phase (days in which $\mu m$ is achieved), and $t$ : incubation time (days).

The three mathematical models (Gompertz, logistic and transference) determine $N, \mu m$ and $\lambda$, minimizing the sum of the squares of the discrepancy between experimental curves from BMP assays, and expected curves from model equations (equations $2-4)$. In order to determine the correlation of the models to the experimental curves, the correlation coefficient $r$ was also calculated. A confidence interval of $95 \%$ was established for the goodness-of-fit of the expected curves.

\section{Analytical methods}

Total solids (TS) and VS of vinasses and inocula were measured according to VDI-4630 (VDI 2016). COD was measured according to the norm DIN (1986). For sugar content analysis a digital refractometer from HANNA Instruments HI 96801 was used. Total dissolved solids (TDS) and conductivity were measured with a HI98311 waterproof tester from HANNA Instruments. The $\mathrm{pH}$ values were measured with VWR $\mathrm{pH} 110$. The volatile organic acids/total inorganic carbon (FOS/TAC, German acronym) value was measured to analyze the inocula biochemical state (Moerschner 2015). FOS/TAC is the quotient of the volatile organic acids and the total inorganic carbonate. FOS/TAC shows the relation between the acid concentration and the buffer capacity of the bioreactor. FOS indicates in terms of $\mathrm{mg} / \mathrm{L} \mathrm{HAc}$ the volatile organic acids or volatile fatty acids (VFA, mostly acetic acid), and TAC shows the total inorganic carbonate in terms of $\mathrm{mgCaCO}_{3} / \mathrm{L}$ (Buchauer 1998, Mézes et al. 2011). An optimal FOS/TAC value should oscillate between 0.3 and 0.6 , depending on the fermentation substrate (Lossie and Pütz 2008).

\section{Statistical analysis}

All the experiments were carried out in triplicate. Biogas and methane yields were expressed as mean values with the corresponding standard deviation. By means of the Minitab 15 software, a $2^{\mathrm{k}}$ factorial design was performed at a $95 \%$ confidence level to analyze the effect of the interactions of three input variables on the cumulative methane yield. The variables or factors analyzed were vinasses content, daily methane content and daily biogas produced. Manure and sludge were analyzed separately, due to the different SI-ratios used.

\section{RESULTS}

\section{Biogas and methane yields}

Table III shows the results of the cumulative biogas $\left(B_{\mathrm{T}}\right)$ and methane $\left(M_{\mathrm{T}}\right)$ yields using anaero- 
TABLE III. BIOGAS YIELD, METHANE YIELD AND REQUIRED TIME IN DAYS TO ACHIEVE 25, 50 AND $75 \%$ OF THE TOTAL PRODUCTION, WITH DIFFERENT INOCULA AND SUBSTRATE:INOCULUM-RATIO (SI)

\begin{tabular}{|c|c|c|c|c|c|c|c|c|c|}
\hline & $\begin{array}{l}\text { Time } \\
\text { (days) }\end{array}$ & $\begin{array}{c}\mathrm{B}_{\mathrm{T}} \\
\left(\mathrm{L}_{\text {biogas }} / \mathrm{kgVS}\right)\end{array}$ & $\begin{array}{l}25 \% \\
\text { of } \mathrm{B}_{\mathrm{T}} \\
\text { (days) }\end{array}$ & $\begin{array}{l}50 \% \\
\text { of } \mathrm{B}_{\mathrm{T}} \\
\text { (days) }\end{array}$ & $\begin{array}{l}75 \% \\
\text { of } \mathrm{B}_{\mathrm{T}} \\
\text { (days) }\end{array}$ & $\begin{array}{c}\mathrm{M}_{\mathrm{T}} \\
\left(\mathrm{L}_{\mathrm{CH} 4} / \mathrm{kgVS}\right)\end{array}$ & $\begin{array}{l}25 \% \\
\text { of } \mathrm{M}_{\mathrm{T}} \\
\text { (days) }\end{array}$ & $\begin{array}{l}50 \% \\
\text { of } \mathrm{M}_{\mathrm{T}} \\
\text { (days) }\end{array}$ & $\begin{array}{l}75 \% \\
\text { of } \mathrm{M}_{\mathrm{T}} \\
\text { (days) }\end{array}$ \\
\hline Sludge SI 0.1 & 26 & $460.87 \pm 65.48$ & 2 & 2 & 4 & $87.83 \pm 5.06$ & 2 & 2 & 4 \\
\hline Sludge SI 0.3 & 26 & $523.02 \pm 16.00$ & 2 & 4 & 10 & $188.46 \pm 10.34$ & 2 & 4 & 9 \\
\hline Sludge SI 0.4 & 26 & $72.19 \pm 7.45$ & 2 & 4 & 7 & $28.16 \pm 0.34$ & 2 & 5 & 10 \\
\hline Manure SI 0.3 & 30 & $1025.44 \pm 33.80$ & 8 & 11 & 17 & $598.92 \pm 33.34$ & 9 & 12 & 18 \\
\hline Manure SI 0.5 & 30 & $377.05 \pm 5.82$ & 2 & 26 & 28 & $205.94 \pm 10.18$ & 24 & 26 & 28 \\
\hline Manure SI 0.7 & 30 & $192.81 \pm 21.56$ & 2 & 3 & 29 & $32.19 \pm 2.44$ & 30 & 30 & 30 \\
\hline
\end{tabular}

$\mathrm{B}_{\mathrm{T}}$ : biogas yield, $\mathrm{M}_{\mathrm{T}}$ : methane yield, VS: volatile solids

bic sludge and cattle manure as inoculum, with the different SI-ratios tested. The time of each assay (d) differs between each inoculum source, due to the test termination criteria (VDI 2016). Table III shows also the required time in order to achieve 25, 50 and $75 \%$ of $B_{\mathrm{T}}$ and $M_{\mathrm{T}}$.

For sludge and manure as inoculum, the highest biogas and methane yields were produced using an SI-ratio of 0.3. In comparison to sludge, manure produced twice more biogas (1025.44 \pm 33.80 against $523.02 \pm 16.00 \mathrm{~L} / \mathrm{kgVS}$ ) and three times more methane $\left(598.92 \pm 33.34\right.$ against $188.46 \pm 10.34 \mathrm{~L}_{\mathrm{CH} 4} /$ $\mathrm{kgVS})$. The highest SI-ratios generated the lowest biogas and methane yields. SI-ratios of 0.5 and 0.7 showed a lower $\mathrm{AD}$ efficiency, in comparison to control tests (with only inoculum). By day 4, control assays produced $56 \%$ more methane than SI-ratio 0.7 , and by day 7 produced $10 \%$ more methane than SI-ratio 0.5. After day 24, control assays showed again lower values than SI-ratios 0.5 and 0.7.

Regarding the required time to achieve 25,50 and $75 \%$ of the cumulative biogas $B_{\mathrm{T}}$ and methane $M_{\mathrm{T}}$ yield, even though sludge showed lower methane yield, it showed also a faster digestion time. All sludge assays showed $25 \%$ of $B_{\mathrm{T}}$ and $M_{\mathrm{T}}$ already by the second day and $50 \%$ by days 4 or 5 . In the case of manure, only $B_{\mathrm{T}}$ of 0.5 and 0.7 ratios showed 25 $\%$ by the second day. $M_{\mathrm{T}}$ was much slower, whereas $25 \%$ was achieved by days 24 and 30, respectively. The highest achieved $B_{\mathrm{T}}$ and $M_{\mathrm{T}}$ (manure SI-ratio 0.3 ) showed a slow degradation time: $25 \%$ was achieved by days $8-9,50 \%$ by days $11-12$, and $75 \%$ by days $17-18$.

When analyzing the cumulative methane yield of sludge in figure 3, the methane production of SI-ratio 0.3 was twice as much as SI-ratio 0.1 and six times higher than SI-ratio 0.4. For all the ratios tested, the highest increase in methane production can be seen between the first and second days. The curve for ratio 0.1 showed a remarked increment during the first eight days. Afterwards only a slightly increment can be appreciated. SI-ratios 0.3 and 0.4 showed an increment until day 19; afterwards the curve showed constant values. Regarding the daily methane content in biogas, the highest content for SI-ratio 0.3 was 46.8 $\%$ by the third day. SI-ratio 0.1 reached the highest methane content by day six producing $24.4 \%$ and SI-ratio 0.4 produced $28.7 \%$ by day three.

Regarding the assays with manure, the highest methane production achieved was $598.92 \pm 33.34$ $\mathrm{L}_{\mathrm{CH} 4} / \mathrm{kgVS}$ with SI-ratio 0.3, increasing the methane content significantly after the sixth day (Fig. 4). SI-ratios 0.5 and 0.7 showed a lower AD efficiency than control tests, where only manure was digested. SI-ratio 0.5 did not produce a significant methane amount until day 24 and SI-ratio 0.7 until day 28. By the end of the BMP assays, the total methane production achieved was $205.94 \pm 10.18 \mathrm{~L}_{\mathrm{CH}} / \mathrm{kgVS}$ for SI-ratio 0.5 and $32.19 \pm 2.44 \mathrm{~L}_{\mathrm{CH}} / \mathrm{kgVS}$ for SIratio 0.7 . In terms of percentage, the daily methane content in biogas was $81 \%$ by the 10th day, when digesting SI-ratio 0.3; further measurements varied between 70 and $75 \%$. Tests with SI-ratio 0.5 showed the highest methane content of $77.4 \%$ by day 26 and SI-ratio 0.7 showed $73.6 \%$ methane by day 28 .

\section{Kinetic study}

By means of the modified Gompertz model, logistic model and transference function, variables were determined in regard to the maximum methane production potential $\left(M_{\mathrm{T}}\right)$, maximum specific methane yield growth $(\mu m)$ and lag phase $(\lambda)$. The results of these three mathematical models of sigmoidal bacterial growth were plotted against the average cumulative methane yields from the BMP tests, for sludge and manure (Figs. 3 and 4, respectively). The 

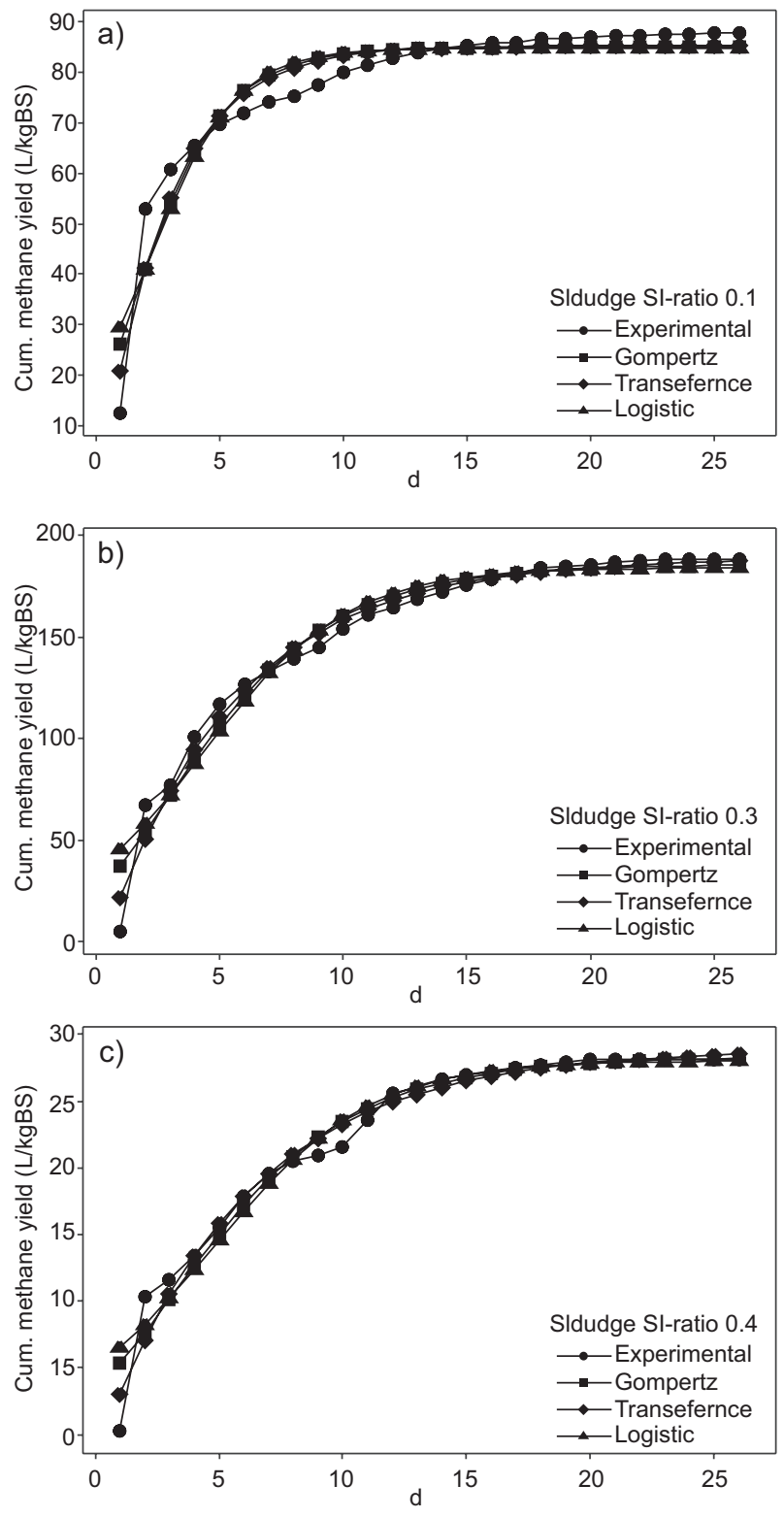

Fig. 3. Cumulative methane yield using sludge as inoculum (experimental data and data fitted to mathematical models)

parameters calculated from the non-linear regression, as well as the coefficient $r$ and the difference between experimental and predicted $M_{\mathrm{T}}(\%$ error $)$ are shown in table IV.

Regarding the use of sludge as inoculum, SI-ratios 0.3 and 0.4 showed visually good fits between the three mathematical models and the experimental data, with $r>0.95$. Nevertheless, SI-ratio 0.1 showed a lower correlation between experimental and predicted curves, with a lower $r$ of 0.90 . Gompertz and logistic models showed minimal variances between
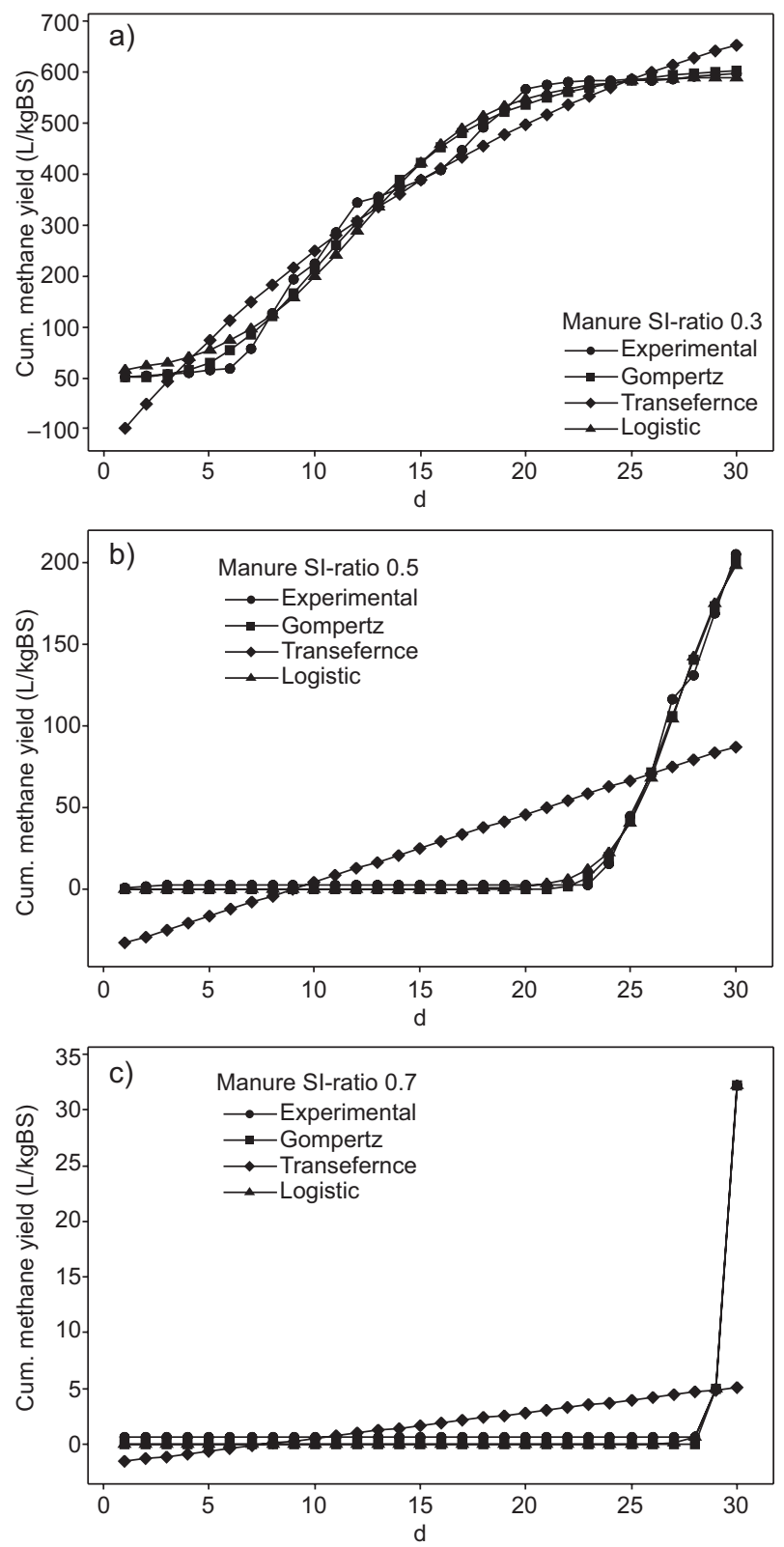

Fig. 4. Cumulative methane yield using manure as inoculum (experimental data and data fitted to mathematical models)

the parameters $M_{\mathrm{T}}, \mu m$ and $\lambda$. Regarding the transference function, $M_{\mathrm{T}}$ showed also minimal variances between curves, but values of $\mu m$ and $\lambda$ were much higher in comparison to Gompertz and logistic models. The highest $\%$ error between experimental and theoretical $M_{\mathrm{T}}$ was 3.56 for SI-ratio 0.1. Concerning the curves, there was no visual difference between the slopes of each SI-ratio, but comparing the parameter $\mu m$, which increments with a steeper slop, the high- 
est value was shown with SI-ratio 0.3. The lowest $\mu m$ was given by SI-ratio 0.4 . $\lambda$ was almost 0 for all three SI-ratios.

When analyzing data for manure, both Gompertz and logistic curves provided accurate visual fits to the experimental data showing a $r$ of 0.99 . The transference function did not show good fits, especially for SI-ratios 0.5 and 0.7 , which demonstrated also a very low $\mathrm{r}$ of 0.45 and 0.12 , respectively.

Regarding the percentage error between experimental and theoretical $M_{\mathrm{T}}$, SI-ratio 0.3 evaluated with Gompertz and logistic models showed low values of 1.01 and 2.09, which are accurate and comparable to the errors found using sludge. The transference function showed much higher errors of $35.12 \%$ for SI-ratio 0.3 and almost $100 \%$ for SI-ratios 0.5 and 0.7. The Gompertz model indicated errors of 19.72 and $30.96 \%$ for SI-ratios 0.7 and 0.5, and the logistic model showed errors of 67.02 and 10.91. Therefore, Gompertz indicated more accurate results for SI-ratio 0.7, and logistic for SI-ratios 0.3 and 0.5 . If the slope of the curve is evaluated according to the models that show the lowest percentage error, it can be inferred that the steepest slope was given by SI-ratio 0.3 with a $\mu \mathrm{m}$ of 47.34 in comparison to 39.00 and 33.23 for SIratios 0.5 and 0.7 . It is important to notice that this information cannot be clearly estblished from the cumulative curves but can only be inferred due to $\mu m$ values in table IV. The smallest value of $\lambda$ was obtained with SI-ratio 0.3, which also showed the highest $M_{\mathrm{T}}$. The lag phase for SI-ratios 0.5 and 0.7 was around 24 and 29 days, respectively. The best fits to a normal bacterial growth curve (Fig. 1) were generated by the assays with manure at SI-ratio 0.3, which showed also the highest AD efficiency.

TABLE IV. KINETIC PARAMETERS OF CUMULATIVE METHANE PRODUCTION CURVES: METHANE YIELD, MAXIMUM SPECIFIC METHANE GROWTH YIELD

\begin{tabular}{|c|c|c|c|c|c|c|c|}
\hline & Models & $\begin{array}{c}\mathrm{M}_{\mathrm{T}} \text { experimental } \\
\left(\mathrm{L}_{\mathrm{CH} 4} / \mathrm{kgVS}\right)\end{array}$ & $\begin{array}{c}\mathrm{M}_{\mathrm{T}} \text { theoretical } \\
\left(\mathrm{L}_{\mathrm{CH} 4} / \mathrm{kgVS}\right)\end{array}$ & $\underset{\left(\mathrm{L}_{\mathrm{CH} 4} / \mathrm{kgVS} * \mathrm{~d}\right)}{\mu \mathrm{m}}$ & $\lambda(\mathrm{d})$ & $\mathrm{r}$ & $\begin{array}{l}\% \text { error } \mathrm{M}_{\mathrm{T}} \\
\exp / \mathrm{M}_{\mathrm{T}} \text { theo }\end{array}$ \\
\hline $\begin{array}{l}\text { Sludge } \\
\text { S:I-ratio } 0.1\end{array}$ & $\begin{array}{l}\text { Experimental } \\
\text { Gompertz } \\
\text { Transference } \\
\text { Logistic }\end{array}$ & $87.83 \pm 5.06$ & $\begin{array}{l}85.00 \\
85.36 \\
84.81\end{array}$ & $\begin{array}{l}14.98 \\
32.63 \\
12.14\end{array}$ & $\begin{array}{r}-0.74 \\
0.27 \\
-1.38\end{array}$ & $\begin{array}{l}0.91 \\
0.94 \\
0.90\end{array}$ & $\begin{array}{l}3.32 \\
2.89 \\
3.56\end{array}$ \\
\hline $\begin{array}{l}\text { Sludge } \\
\text { S:I-ratio } 0.3\end{array}$ & $\begin{array}{l}\text { Experimental } \\
\text { Gompertz } \\
\text { Transference } \\
\text { Logistic }\end{array}$ & $188.46 \pm 10.34$ & $\begin{array}{l}185.65 \\
188.80 \\
184.09\end{array}$ & $\begin{array}{l}18.13 \\
35.84 \\
15.68\end{array}$ & $\begin{array}{r}-0.98 \\
0.35 \\
-1.60\end{array}$ & $\begin{array}{l}0.97 \\
0.98 \\
0.95\end{array}$ & $\begin{array}{l}1.51 \\
0.18 \\
2.37\end{array}$ \\
\hline $\begin{array}{l}\text { Sludge } \\
\text { S:I-ratio } 0.4\end{array}$ & $\begin{array}{l}\text { Experimental } \\
\text { Gompertz } \\
\text { Transference } \\
\text { Logistic }\end{array}$ & $28.16 \pm 0.34$ & $\begin{array}{l}28.31 \\
28.89 \\
28.03\end{array}$ & $\begin{array}{l}2.53 \\
4.90 \\
2.23\end{array}$ & $\begin{array}{r}-0.99 \\
0.34 \\
-1.52\end{array}$ & $\begin{array}{l}0.97 \\
0.98 \\
0.96\end{array}$ & $\begin{array}{l}0.52 \\
2.52 \\
0.46\end{array}$ \\
\hline $\begin{array}{l}\text { Manure } \\
\text { S:I-ratio } 0.3\end{array}$ & $\begin{array}{l}\text { Experimental } \\
\text { Gompertz } \\
\text { Transference } \\
\text { Logistic }\end{array}$ & $598.92 \pm 33.34$ & $\begin{array}{l}611.71 \\
923.14 \\
592.92\end{array}$ & $\begin{array}{l}47.30 \\
42.59 \\
47.34\end{array}$ & $\begin{array}{l}5.51 \\
3.20 \\
5.90\end{array}$ & $\begin{array}{l}0.99 \\
0.96 \\
0.99\end{array}$ & $\begin{array}{r}2.09 \\
35.12 \\
1.01\end{array}$ \\
\hline $\begin{array}{l}\text { Manure } \\
\text { S:I-ratio } 0.5\end{array}$ & $\begin{array}{l}\text { Experimental } \\
\text { Gompertz } \\
\text { Transference } \\
\text { Logistic }\end{array}$ & $205.94 \pm 10.18$ & $\begin{array}{c}298.31 \\
2396326289.63 \\
231.17\end{array}$ & $\begin{array}{r}35.41 \\
4.17 \\
39.00\end{array}$ & $\begin{array}{r}24.01 \\
8.99 \\
24.33\end{array}$ & $\begin{array}{l}0.99 \\
0.45 \\
0.99\end{array}$ & $\begin{array}{l}30.96 \\
99.99 \\
10.91\end{array}$ \\
\hline $\begin{array}{l}\text { Manure } \\
\text { S:I-ratio } 0.7\end{array}$ & $\begin{array}{l}\text { Experimental } \\
\text { Gompertz } \\
\text { Transference } \\
\text { Logistic }\end{array}$ & $32.19 \pm 2.44$ & $\begin{array}{c}40.10 \\
322504388.03 \\
97.63\end{array}$ & $\begin{array}{r}33.23 \\
0.23 \\
54.00\end{array}$ & $\begin{array}{r}28.88 \\
7.82 \\
29.42\end{array}$ & $\begin{array}{l}0.99 \\
0.12 \\
0.99\end{array}$ & $\begin{array}{l}19.72 \\
99.99 \\
67.02\end{array}$ \\
\hline
\end{tabular}

$M_{\mathrm{T}}$ : methane yield, $\mu m$ : maximum specific methane growth yield, $\lambda:$ lag phase, VS: volatile solids, d: days, r: correlation coefficient, SI-ratio: substrate:inoculum-ratio 
TABLE V. REMOVAL OF TOTAL AND VOLATILE SOLIDS

\begin{tabular}{|c|c|c|c|c|c|c|}
\hline & Initial & Final & \multirow{2}{*}{ TS removal } & Initial & Final & \multirow{2}{*}{$\begin{array}{c}\text { VS } \\
\text { removal }\end{array}$} \\
\hline & \multicolumn{2}{|c|}{$\mathrm{TS}$} & & \multicolumn{2}{|c|}{ VS } & \\
\hline & \multicolumn{2}{|c|}{$\%$} & $\%$ & \multicolumn{2}{|c|}{$\%$} & $\%$ \\
\hline Sludge SI-ratio 0.1 & 2.60 & 2.50 & 3.85 & 1.87 & 1.68 & 10.16 \\
\hline Sludge SI-ratio 0.3 & 2.80 & 2.09 & 25.36 & 2.00 & 1.42 & 29.00 \\
\hline Sludge SI-ratio 0.4 & 2.65 & 2.49 & 6.04 & 1.89 & 1.64 & 13.23 \\
\hline Manure SI-ratio 0.3 & 4.87 & 3.00 & 38.40 & 3.64 & 1.67 & 54.12 \\
\hline Manure SI-ratio 0.5 & 5.52 & 3.49 & 36.78 & 3.61 & 1.74 & 51.80 \\
\hline Manure SI-ratio 0.7 & 6.29 & 4.08 & 35.14 & 4.05 & 2.00 & 50.62 \\
\hline
\end{tabular}

TS: total solids, VS: volatile solids

\section{Total and volatile solids}

The results regarding TS and VS removal are shown in table $\mathbf{V}$. In both cases, the highest removals were achieved with SI-ratio 0.3, which generated the highest biogas and methane yields. The digestion of vinasses and manure achieved TS and VS removals of $35-38 \%$ and $50-54 \%$, respectively. When digesting vinasses and sludge, TS and VS removals differed much more between every concentration. TS and VS removals were around 3.85 and $10.16 \%$ for sludge SI-ratio 0.1, 25.36 and 29 $\%$ for sludge SI-ratio 0.3, and 6.04 and $13.23 \%$ for sludge SI-ratio 0.4.

\section{Determination of $\mathrm{pH}$ and FOS/TAC}

Table VI shows the $\mathrm{pH}$, single FOS and TAC, as well as the calculated FOS/TAC values of the assays with manure and sludge. FOS/TAC values began much higher than recommended by Lossie and Pütz (2008); as expected, they reached lower values by the end of the assays.
Regarding the assays with sludge, at the beginning the amount of organic acids increased proportionally to the increase of vinasses content and FOS/TAC value. At the same time, the $\mathrm{pH}$ value decreased and so the amount of inorganic carbonate and thus the buffer capacity. At the end of the assays the buffer capacity, organic acid content as well as FOS/TAC increased with increasing vinasses content, while the $\mathrm{pH}$ value decreased. Regarding the assays with manure, a similar behavior of vinasses content, FOS and FOS/TAC can be appreciated. The more vinasses content, the more organic acids diminishing $\mathrm{pH}$ value. Nevertheless, TAC increased with increased vinasses content, which suggests a higher buffer capacity.

\section{DISCUSSION}

\section{Anaerobic digestion}

Vinasses AD is a very suitable alternative to treat these residues, while generating energy. Jáuregui-

TABLE VI. VOLATILE ORGANIC ACIDS/TOTAL INORGANIC CARBON AND pH VALUES OF SUBSTRATE, INOCULA AND SI-RATIO MEASURED AT THE BEGINNING AND END OF ASSAYS

\begin{tabular}{|c|c|c|c|c|c|c|c|c|}
\hline & $\mathrm{pH}$ & FOS & TAC & FOS/TAC & $\mathrm{pH}$ & FOS & TAC & FOS/TAC \\
\hline & \multicolumn{4}{|c|}{ Initial } & \multicolumn{4}{|c|}{ Final } \\
\hline Sludge & 7.32 & 17853 & 19000 & 0.94 & 8.75 & 257 & 1902 & 0.13 \\
\hline Manure & 8.1 & 5984 & 20500 & 0.29 & 7.99 & 72 & 1495 & 0.04 \\
\hline Sludge SI-ratio 0.1 & 7.1 & 19845 & 20300 & 0.98 & 8.69 & 423 & 1851 & 0.23 \\
\hline Sludge SI-ratio 0.3 & 6.7 & 23497 & 19900 & 1.18 & 8.66 & 589 & 2402 & 0.25 \\
\hline Sludge SI-ratio 0.4 & 6.46 & 25157 & 13700 & 1.84 & 8.04 & 755 & 2252 & 0.34 \\
\hline Manure SI-ratio 0.3 & 7.83 & 4739 & 9300 & 0.51 & 8.03 & 81 & 744 & 0.10 \\
\hline Manure SI-ratio 0.5 & 7.75 & 5320 & 9675 & 0.55 & 8.02 & 144 & 977 & 0.15 \\
\hline Manure SI-ratio 0.7 & 7.7 & 6482 & 9950 & 0.65 & 8.75 & 284 & 1672 & 0.17 \\
\hline
\end{tabular}

FOS/TAC: volatile organic acids/total inorganic carbon (German acronym), SI-ratio: substrate:inoculum-ratio 
Jáuregui et al. (2014) reported 65.\% methane content in biogas when digesting vinasses and brewery sludge. Méndez-Acosta et al. (2010) obtained $60 \%$ methane and Buitrón et al. (2014) obtained $64 \%$. In the present study, the highest methane content achieved was $81 \%$ with a further constant value between 70 and $75 \%$. The highest methane yield achieved in this study was $598.92 \pm 33.34 \mathrm{~L}_{\mathrm{CH} 4} /$ $\mathrm{kgVS}$. In comparison, Fu et al. (2017) generated $274 \mathrm{~L}_{\mathrm{CH}} / \mathrm{kgVS}$ and López González et al. (2017) obtained 365-368 $\mathrm{L}_{\mathrm{CH}} / \mathrm{kgVS}$ when digesting vinasses and sludge. Friehe et al. (2013) published a list regarding biogas yields tested for 32 different biomass sources such as sugar beet, maize silage, organic waste bin or ruminal contents, among others. From the list, only the amniotic fluid and the process water generated a higher biogas yield of 1500-2000 $\mathrm{L} / \mathrm{kgVS}$ and $3000-4500 \mathrm{~L} / \mathrm{kgVS}$, respectively, in comparison to the biogas generation obtained from vinasses in the present assays (1025.44 \pm 33.80 $\mathrm{L} / \mathrm{kgVS}$ ). According to the list, flotation sludge showed a biogas yield of 900-1200 L/kgVS, while all other substrates reported between 200 and $850 \mathrm{~L} /$ $\mathrm{kgVS}$ biogas. Regarding methane content, the highest value in the list of substrates was $75 \%$, achieved by two sugar-rich substrates: molasses and pressed pulp. In the present study, methane content in biogas (manure SI-ratio 0.3) was 70-75\% and reached a peak of $81 \%$, which is higher than reported when digesting other sugar-rich substrates. This suggests that the digestion of cattle manure with vinasses is very suitable for AD. According to Friehe et al. (2013), carbohydrates are a very effective source for $\mathrm{AD}$, due to the fact that sugar, in comparison to fat or protein, is more accessible for bacteria to be biodegraded. Robles-González et al. (2012) reported that vinasses contain high amounts of dissolved solids, from which $50 \%$ are reducing sugars $(4000-5000 \mathrm{mg} / \mathrm{L})$ originated by the condensation of fermented agave juice. Therefore, more biogas and methane can be produced. The total sugar content in vinasses used in assays was $51 \mathrm{~g} / \mathrm{L}$.

Regarding AD using manure as inoculum, methane production started some days after biogas production. This can be explained because AD occurs in four steps. The bacteria groups of each stage reproduce at different rates in order to produce acetic acid, hydrogen and carbon dioxide for the methane formation (Friehe et al. 2013). Methanogenic bacteria have the slowest reproduction rate of all, up to 360 $\mathrm{h}$ for methanosarcina or $240 \mathrm{~h}$ for methanococcus. Hydrolytic and acidogenic bacteria need between 24 and $36 \mathrm{~h}$ to reproduce, while acetogenic bacteria from 40 to $132 \mathrm{~h}$ (KWS 2009). Methanogenesis is the slowest step to methane generation.

The most favorable $\mathrm{pH}$ value for $\mathrm{AD}$ should be between 6.5 and 7.5. If $\mathrm{pH}$ lies under 6.5, the methanogenic bacteria metabolism is inhibited, and methanogens cannot degrade biomass at the same rate as hydrolytic and acidogenic bacteria. An accumulation of acids from the acidogenic stage takes place and $\mathrm{pH}$ value drops, moving the $\mathrm{NH}_{4}^{+} / \mathrm{NH}_{3}$ balance to $\mathrm{NH}_{3}$, which could have an inhibition effect (Friehe et al. 2013). If $\mathrm{pH}$ is higher than 8 , the methane yield will be slower (Mézes el at. 2011). This is the case at the end of the assays, when low methane production occurs. If the buffer capacity is not high enough, the change in $\mathrm{pH}$ will be significant. FOS/TAC (table VI) at the end of the assays showed lower values than recommended by Lossie and Pütz (2008), which indicates that the biomass input was far too low, thus an increase in biomass input should reactivate the system in order to maintain an efficient methane production. By the end of the assays the amount of organic acids decreased considerably (97-99\%), which indicates a successful conversion of organic acids in methane.

\section{Si-ratios evaluation}

When comparing the SI-ratios tested, results of BMP assays indicate that the highest biogas and methane yield and the highest organic matter removal were achieved using SI-ratio 0.3. Manure showed the highest efficiency. Syaichurrozi (2014) found that in vinasses $\mathrm{AD}$ a very high organic matter content affects the organic removal rate. Microorganisms experience difficulties in degrading high contents of organic material, especially because methanogenic bacteria do not reproduce at the same rate as hydrolytic or acidogenic bacteria, creating a bottleneck for material degradation. This was the case of the highest SI-ratios tested. The highest SI-ratios, 0.4 for sludge and 0.7 for manure, showed the lowest biogas and methane yields. Between days 5 and 20, SI-ratios of 0.5 and 0.7 showed a lower AD efficiency, in comparison to the control tests (only inoculum). A high amount of organic matter might lead to organic acids accumulation, which could affect the capacity of the microorganisms to degrade organic material. Consequently, $\mathrm{AD}$ and the removal of organic matter is negatively affected. According to Fagbohungbe et al. (2015) if the organic loading rate increases beyond the degradation capacity of the microbial population, volatile fatty acids (VFAs) accumulate and $\mathrm{pH}$ drops, reducing the methanogenic activity. VFAs (organic acids) are intermediate products in $\mathrm{AD}$, 
from which $70 \%$ of the total methane is produced. When increasing the organic loading rate, the organic acid concentration increases causing methanogenesis inhibition. This can explain the results of AD using SI-ratios 0.4 and 0.7 , which showed lower biogas and methane yields, in comparison to smaller SI-ratios. In table VI it can be seen that the amount of organic acids FOS increased at higher SI-ratios with increasing vinasses content. On the other hand, when using SI-ratio 0.3 , the organic load was slightly lower than the microorganism's degradation capacity, preventing an accumulation of VFAs. Zhou et al. (2011) reported higher methanogenic activity by AD of bean curd when using SI-ratios between 0.3 and 0.6 , rather than SI-ratios between 0.7 and 3. Methane production decreased when the substrate load increased. Liu and Sung (2002) reported a significant decrease in the methane conversion efficiency using algal residue as a substrate, when SI-ratios were higher than 1. SI-ratio 0.3 tends to be more promising than SI-ratio 0.5, which is recommended by VDI (2016) in equation 1.

\section{Effect of inoculum sources}

The inoculum source plays a crucial role on the degradation efficiency of polymers and molecules contained in complex substrates such as vinasses. Furthermore, the micronutrients contained in inoculum could enhance the enzymatic activity and thus methane production (Gu et al. 2014).

In the present study, BMP assays with sludge showed $70 \%$ lower methane production than manure (table III). At the beginning and end of the assays the amount of organic acids (FOS), buffer capacity (TAC) and FOS/TAC values incremented proportionally to the vinasses content (higher SI-ratios), except when starting the sludge assays, which showed a decreased buffer capacity (TAC). Assays with manure showed at the beginning of the tests a higher TAC value with increased vinasses content (higher SI-ratio). It can be inferred that manure has a higher buffer capacity than sludge, which suggests a higher balance between ammonium and ammoniac $\mathrm{NH}_{4}^{+} / \mathrm{NH}_{3}$. According to Moerschner (2015), conductivity increases with the increase of salts content, such as ammonium content. It can be said that $10 \mathrm{mS}$ conductivity corresponds to $1 \mathrm{~g} / \mathrm{L} \mathrm{NH}_{4}-\mathrm{N}$. Manure shows in table II a higher conductivity than sludge. Besides, with $\mathrm{pH}$ increase, concentration of the $\mathrm{H}^{+}$-ion might increase and the $\mathrm{NH}_{4}{ }^{+} / \mathrm{NH}_{3}{ }^{-}$balance could had moved to $\mathrm{NH}_{4}{ }^{+}$. Furthermore, FOS/TAC of sludge assays showed higher values than manure assays. The relation between the acid concentration and the buffer capacity of sludge assays was much higher than recommended in the literature and practice (Lossie and Pütz 2008, Mézes et al. 2011, Moerschner 2015).

A high organic acids content $(>10000 \mathrm{mg} / \mathrm{L})$ could result in an incomplete bacterial metabolism, which might lead to inhibition. If at the same time the buffer capacity of the system is adequate, the inhibition will not be evidenced (Mézes el at. 2011). Moerschner (2015) suggested TAC values between 8500 and $13000 \mathrm{mg} / \mathrm{L}$. As in the case of sludge, at the beginning of the assays FOS was higher than 10 $000 \mathrm{mg} / \mathrm{L}$ and inorganic carbonate was higher than $13000 \mathrm{mg} / \mathrm{L}$. This was not the case of manure, which showed a higher $M_{\mathrm{T}}$ in the assays.

Also, the removal rate of organic material had better results when using manure in comparison to sludge. When comparing 0.3 SI-ratios, the digestion of manure removed $10 \%$ more TS and 20.\% more VS than sludge. These results suggest that manure has a better adaptability in vinasses digestion, maybe because it contains microorganisms that produce enzymes, which hydrolyze the vinasses for an efficient AD. Another reason is that the content of volatile organic acids is much higher in sludge than in manure (table II), causing inhibition. Gu et al. (2014) reported similar results when comparing different inoculum sources (digested manure, swine manure, chicken manure, anaerobic granular sludge, municipal sludge and paper mill sludge) for biogas/ methane production using rice straw as substrate. The highest methane production was obtained using manure, especially when using digested manure. It was reported that anaerobic digesters inoculated with manure showed higher and more stable biogas production in comparison to sludge. Córdoba et al. (2015) showed contrary results when comparing sludge and manure as inoculum. Bacteria in manure was not able to consume the available volatiles fatty acids and showed a lower methane generation. Sludge was reported to have more VFAs than manure (1509 $\mathrm{mgCaCO}_{3} / \mathrm{L}$ vs. $\left.1476 \mathrm{mgCaCO}_{3} / \mathrm{L}\right)$. An adequate inoculum and SI-ratio promote VFAs consumption and methane production, otherwise there is an accumulation that could inhibit the methanogenic activity. The efficient $\mathrm{AD}$ process requires a large diversity of methane-forming population and active microbial communities (Gerardi 2003).

According to table III biogas and methane production started earlier using sludge, in comparison to manure. Regarding the assays with sludge, 25, 50 and $75 \%$ of biogas and methane were generated already around days 2, 4 and 9, respectively. Manure took much longer to digest. The faster digestion 
time by sludge may have occurred due to the lower COD, VS and TS content, as compared to manure (table II).

Regarding the statistical analysis, assays with sludge indicated a significant effect between all interactions tested (daily biogas in L, daily methane $\%$ and vinasses content) on the cumulative methane yield. Assays with manure indicated that only the interaction between daily biogas production and vinasses content had a significant effect on the cumulative methane production. These results can be explained due to the fact that the daily methane content for manure assays showed similar values in all SI-ratios tested (73.6-81\%). In the case of sludge, a higher methane content variation was appreciated between SI-ratios (24.4-46.8 \%).

\section{Kinetic study}

Modeling the methane production kinetics provided information regarding the maximum methane production potential ( $\mathrm{L}_{\mathrm{CH}} / \mathrm{kgVS}$ ), maximum specific methane growth $\mu m\left(\mathrm{~L}_{\mathrm{CH}} / \mathrm{kgVS} * \mathrm{~d}\right)$ and the lag phase $\lambda$ (days) in which $\mu m$ was achieved. When comparing the three mathematical models of BMP assays, Gompertz and logistic models showed the best visual fits to the curve, highest $r$, lowest experimental/expected percentage error, and similarity of the parameters $M_{\mathrm{T}}, \mu m$ and $\lambda$.

A high $\mu \mathrm{m}$ indicates a steeper slope and thus a higher specific methane growth rate. In general, sludge assays showed a lower $\mu m$, although the lag phase occurred right at the beginning of the experiments (table IV). In both cases, manure and sludge, SI-ratio 0.3 showed the highest specific methane growth rate. The highest SI-ratios $(0.4$ for sludge and 0.7 for manure) correspond to the slowest growth rate. When comparing the results of the three mathematical models, transference functions showed higher values for $\mu m$ and $\lambda$ for sludge assays, such as in the experiments carried out by Li et al. (2018) digesting food wastes with seed sludge. In the present experiment, the transference function of manure assays showed lower $\mu m$ and $\lambda$ values.

The percentage of error obtained in the assays with all sludge SI-ratios and manure SI-ratio 0.3 $(<3.5 \%)$ was low, in comparison to the assays with manure SI-ratios 0.5 and 0.7 (>20\%). For these two last SI-ratios, transference functions showed much higher percentages of error. Errors up to 8.7 or $10 \%$ have been reported when digesting water hyacinth or sunflower oil cake (Raposo et al. 2009, Patil et al. 2012).
All three sludge SI-ratios show a negative $\lambda$ for Gompertz and logistic models. According to Li et al. (2018) a negative $\lambda$ indicates that the soluble organics in substrate (in this case sugar) were quickly consumed by the bacteria. In the case of manure, the smallest value of $\lambda$ (approximately 5) was achieved with SI-ratio 0.3. The small $\lambda$ of the assays with sludge indicates that the time to achieve the maximum methane growth rate was shorter than the assays with manure. This could had happened due to the lower amount of soluble organic matter in sludge, in terms of percentage VS and TS, as well as COD (table II). The $\lambda$ for SI-ratios 0.5 and 0.7 was around 24 and 29 days, respectively. As reported by Ware and Power (2017), $\lambda$ zero indicates a high bioavailability of organic degradable compounds. This can be supported by table III, where biogas and methane production whit sludge started faster than manure; it is also confirmed when comparing the percentage error of experimental and theoretical $M_{\text {T. }}$ A good fitting within the theoretical and experimental methane production curves implies an uncomplicated digestion of the substrate, without AD inhibitions (Ware and Power 2017). This was not the case for the use of manure with SI-ratios 0.5 and 0.7 , which had high vinasses content and showed inhibition.

The correlation coefficient $r$ measures how strong is the relationship between experimental and predicted methane curves. If $\mathrm{r}$ approaches to 1 , the correlation is stronger, approaching zero, no correlation can be determined. The coefficient $r$ was $>0.9$ in almost all the cases, except for manure SI-ratios 0.5 and 0.7 evaluated by the transference function. This suggests the inadequacy of this last mathematical model to describe the methane production kinetics. A discrepancy between a high percentage error and a high correlation coefficient in the Gompertz and logistic models is seen with SI-ratios 0.5 and 0.7 . This fact highlights the necessity of considering not only the correlation coefficient, but also the percentage of error between experimental and theoretical data. The findings suggest that the transference function overestimated the theoretical curve of manure SIratio 0.3 by $35.12 \%$, while all models overestimated the theoretical curve for SI-ratios 0.5 and 0.7 even by $99.99 \%$.

The transference model for SI-ratios 0.5 and 0.7 showed an very high theoretical $M_{\mathrm{T}}$, and low $\mu m$ and $\lambda$ compared to the Gompertz and logistic models. Nevertheless, the best visual fits to the mathematical models are shown by assays resulting in the highest anaerobic digestion (SI-ratio 0.3). 


\section{CONCLUSIONS}

Vinasses as substrate for AD are more efficient than other substrates, due to the amount of soluble sugars they contain. Anaerobic sludge was digested with vinasses at SI-ratios of 0.1, 0.3 and 0.4 , and manure at $0.3,0.5$ and 0.7 . From all SI-ratios tested, SI-ratio 0.3 for sludge and manure produced the highest biogas and methane yield, as well as organic matter removal (\% TS and \% VS). At the end of the assays, the amount of volatile organic acids was reduced almost $99 \%$, which suggests an efficient conversion of organic acids to methane. The highest SI-ratios tested (0.4 and 0.7) showed the lowest biogas and methane production. When analyzing the FOS/TAC value, these two SI-ratios showed the highest organic acid content in comparison to lower SI-ratios using the same inoculum. On the other hand, FOS/TAC values of assays with sludge were much higher than assays with manure. This fact indicates that the relation between the acid concentration and the buffer capacity of assays with sludge is higher than recommended in the literature and practice. Manure SI-ratio 0.3 resulted in the highest biogas yield of $1025.44 \pm 33.80 \mathrm{~L} / \mathrm{kgVS}$, obtaining also the highest methane content of 81 $\%$. Manure showed to have a higher buffer capacity than sludge, suggesting a higher balance between the ammonium ion and ammonia $\left(\mathrm{NH}_{4}{ }^{+} / \mathrm{NH}_{3}\right)$. The conductivity of manure was $28.24 \mathrm{mS}$ in comparison to $12.98 \mathrm{mS}$ of sludge that indicates a higher $\mathrm{NH}_{4}{ }^{+}-$ $\mathrm{N}$ content in manure. The kinetic study showed the inadequacy of using the transference function for modeling methane production of vinasses. When considering both sludge and manure, SI-ratio 0.3 showed better visual fits within the mathematical model and the experimental curves. In comparison to sludge, manure indicated a steeper slope, with higher $\mu m$ values and higher $\lambda$. It can be inferred that the specific methane growth rate is higher for manure, though the methane production rate was achieved much later than sludge, which showed a lag phase of zero. A small lag phase indicates a high bioavailability of organic matter for digestion. When using a higher vinasses content (manure 0.5 and 0.7 ), the percentage of error between experimental and expected methane curves was much higher. This indicates a difficult anaerobic digestion when digesting high organic contents. The best visual fits to the sigmoidal curves resulted with the assay having the highest anaerobic digestion efficiency (manure SI-ratio 0.3). The results of the kinetic study suggest that the transference model is not accurate to describe these experimental data. The present work opens new perspectives for digestion of vinasses with cattle manure, in comparison to conventional use of sludge for AD. The digestion of vinasses with manure as inoculum is suggested at SI-ratio 0.3, to enhance methane and biogas production, organic matter removal, and the overall effectivity of the system.

\section{REFERENCES}

Altaş L. (2009). Inhibitory effect of heavy metals on methane-producing anaerobic granular sludge. J. Hazard. Mater. 162 (2-3), 1551-1556.

DOI: 10.1016/j.jhazmat.2008.06.048

Buchauer K. (1998). A comparison of two simple titration procedures to determine volatile fatty acids in influents to waste-water and sludge treatment processes. Water S.A. 24 (1), 49-56.

Buitrón G., Kumar G., Martínez-Arce A. and Moreno G. (2014). Hydrogen and methane production via a twostage processes (H2-SBR D CH4-UASB) using Tequila vinasses. Int. J. Hydrog. Energy. 39 (33), 19249-19255. DOI: 10.1016/j.ijhydene.2014.04.139

Córdoba V., Fernández M. and Santalla E. (2015). The effect of different inoculums on anaerobic digestion of swine wastewater. J. Environ. Chem. Eng. 4 (1), 115-122. DOI: 10.1016/j.jece.2015.11.003

DIN (1986). DIN 38414-9:1986-09. German standard methods for the examination of water, wastewater and sludge; sludge and sediments (group S); determination of the chemical oxygen demand (COD) (S 9). Deutsches Institut für Normung. Beuth editorial, September.

Dong L., Xianbo H., Qingjing W., Yuexiang Y., Zhiying Y., Zhidong L., Yajun H. and Xiaofeng L. (2016). Kinetics of methane production and hydrolysis in anaerobic digestion of corn stover. Energy 102 (C), 1-9.

DOI: 10.1016/j.energy.2016.02.074

El-Mashad H.M. (2013). Kinetics of methane production from the codigestion of switchgrass and Spirulina platensis algae. Bioresour. Technol. 132, 305-312. DOI: 10.1016/j.biortech.2012.12.183

Espinoza-Escalante F.M., Pelayo-Ortiz C., GutiérrezPulido H., González-Álvarez V., Alcaraz-González V. and Bories A. (2008). Multiple response optimization analysis for pretreatments of Tequila's stillages for VFAs and hydrogen production. Bioresour. Technol. 99 (13), 5822-5829. DOI: 10.1016/j.biortech.2007.10.008

Facchin V., Cavinato C., Fatone F., Pavan P., Cecchi F. and Balzonella D. (2012). Effect of trace elements supplementation on the mesophilic anaerobic digestion 
of foodwaste in batch trials: The influence of inoculum origin. Biochem. Eng. J. 70, 71-77.

DOI: $10.1016 /$ j.bej.2012.10.004

Fagbohungbe M., Herbert B.M.J., Li H., Ricketts L. and Semple K. (2015). The effect of substrate to inoculum ratios on the anaerobic digestion of human faecal material. Environmental Technology and Innovation 3, 121-129. DOI: 10.1016/j.eti.2015.02.005

Friehe J., Weiland P. and Schattauer A. (2013). Grundlagen der anaeroben Fermentation. In: Leitfaden Biogas von der Gewinnung zur Nutzung. Fachagentur Nachwachsende Rohstoffe Publisher, Gülzow-Prüzen, Germany, pp. 21-24.

Fu S.-F., Xu X.-H., Dai M., Yuan X.-Z. and Guo R.-B. (2017). Hydrogen and methane production from vinasse using two-stage anaerobic digestion. Process Saf. Environ. Prot. 107, 81-86.

DOI: $10.1016 /$ j.psep.2017.01.024

Gerardi M.H. (2003). Methane-forming bacteria. In: The microbiology of anaerobic digesters. (Gerardi M.H., Ed.). John Wiley and Sons Inc., New Yersey, USA, pp. 17-29.

Gu Y., Chen X., Liu Z., Zhou X. and Zhang Y. (2014). Effect of inoculum sources on the anaerobic digestion of rice straw. Bioresour. Technol. 158, 149-155.

DOI: 10.1016/j.biortech.2014.02.011

Hidalgo D. and Martín-Marroquín J.M. (2014) Effects of inoculum source and co-digestion strategies on anaerobic digestion of residues generated in the treatment of waste vegetable oils. J. Environ. Manage. 142, 17-22. DOI: 10.1016/j.jenvman.2014.04.004

Jáuregui-Jáuregui J.A., Méndez-Acosta H.O., GonzálezÁlvarez V., Snell-Castro R., Alcaraz-González V. and Godon J.J. (2014). Anaerobic treatment of Tequila vinasses under seasonal operating conditions: Startup, normal operation and restart-up after a long stop and starvation period. Bioresour. Technol. 168, 33-40. DOI: $10.1016 /$ j.biortech.2014.04.006

KWS (2009). Biogas, Grundlagen der Gaerbiologie. Kleinwanzlebener Saatzucht AG [online]. http:// www.biowk.de/images/Medien/PDF/083 Grundlagen_der_G\%C3\%A4rbiologie_2009.pdf 02/04/2018

Li Y., Jin Y., Li H., Borrion A., Yu Z. and Li J. (2018) Kinetic studies on organic degradation and its impacts on improving methane production during anaerobic digestion of food waste. Appl. Energ. 213, 136-147. DOI: $10.1016 /$ j.apenergy/2018.01.033

Liu T. and Sung S. (2002). Ammonia inhibition on thermophilic aceticlastic methanogens. Water Sci. Technol. 45 (10), 113-120.

DOI: $10.2166 /$ wst.2002.0304

López González L.M., Pereda Reyes I. and Romero Romero O. (2017). Anaerobic co-digestion of sugar- cane press mud with vinasse on methane yield. Waste Manage. 68, 139-145.

DOI: 10.1016/j.wasman.2017.07.016

Lossie U. and Pütz P. (2008). Targeted control of biogas plants with the help of FOS/TAC [online]. https:// tr.hach.com/asset-get.download.jsa? $\mathrm{id}=25593611361$ $16 / 02 / 2018$

Méndez-Acosta H.O., Snell-Castro R., Alcaraz-González V., González-Alvarez V. and Pelayo-Ortiz C. (2010). Anaerobic treatment of Tequila vinasses in a CSTRtype digester. Biodegradation 21 (3), 357-363.

DOI: $10.1007 / \mathrm{s} 10532-009-9306-7$

Mézes L., Biró G., Sulyok E., Petis M., Borbély J. and Tamás J. (2011). Novel approach of the basis of FOS/ TAC method. Proceedings. International Symposia "Risk Factors for Environment and Food Safety", "Natural Resources and Sustainable Development" and "50 Years of Agriculture Researche in Oradea". Oradea, Romania, November [online]. https:// www.researchgate.net/profile/Lili_Mezes/publication/251880383_Novel_approach_of_the_basis_of_ FOSTAC_method/links/0c96051f $2 \overline{3} \mathrm{f} 7 \overline{9} 785 \overline{1} 12000000 /$ Novel-approach-of-the-basis-of-FOS-TAC-method. pdf?origin=publication_detail 15/10/2018

Moerschner J. (2015). Anleitung zur Ermittlung des FOS/ TAC mittels Titration [online]. http:/www.fermenterdoktor.com/FD-web-content/download/B07-02_FermenterDoktor Titrieranleitung.pdf 03/02/2018

Patil J.H., Raj M.A., Muralidhara P.L., Desai S.M. and Mahadeva Raju G.K. (2012). Kinetics of anaerobic digestion of water hyacinth using poultry litter as inoculum. Int. J. Environ. Sci. Dev. 3 (2), 94-98.

DOI: 10.7763/IJESD.2012.V3.195

Raposo F., Borja R., Martín M., Martín A., De la Rubia M. and Rincon B. (2009). Influence of inoculum-substrate ratio on the anaerobic digestion of sunflower oil cake in batch mode: process stability and kinetic evaluation. Chem. Eng. J. 149 (1), 70-77.

DOI: $10.1016 /$ j.cej.2008.10.001

Robles-González V., Galíndez-Mayer J., RinderknechtSeijas N. and Poggi-Varaldo H.M. (2012). Treatment of Mezcal vinasses: A review. J. Biotechnol. 157 (4), 524-546. DOI: 10.1016/j.jbiotec.2011.09.006

Rolfe M.D., Rice C.J., Lucchini S., Pin C., Thompson A., Cameron A.D.S., Alston M., Stringer M.F., Betts R.P., Baranyi J., Peck M.W. and Hinton J.C D. (2012). Lag phase is a distinct growth phase that prepares bacteria for exponential growth and involves transient metal accumulation. J. Bacteriol. 194 (3), 686-701. DOI: 10.1128/JB.06112-11

Slimane K., Fathya S., Assia K. and Hamza M. (2014). Influence of inoculums/substrate ratios (ISRs) on the mesophilic anaerobic digestion of slaughterhouse 
waste in batch mode: Process stability and biogas production. Enrgy. Proced. 50, 57-63.

DOI: 10.1016/j.egypro.2014.06.007

Strömberg S., Nistor M. and Liu J. (2014). Towards eliminating systematic errors caused by the experimental conditions in biochemical methane potential (BMP) tests. Waste Manage. 34 (11), 1939-1948.

DOI: 10.1016/j.wasman.2014.07.018

Syaichurrozi I., Budiyono and Sumardiono S. (2013). Predicting kinetic model of biogas production and biodegradability organic materials: biogas production from vinasse at variation of $\mathrm{COD} / \mathrm{N}$ ratio. Bioresour. Technol. 149, 390-397.

DOI: $10.1016 /$ j.biortech.2013.09.088

Syaichurrozi I. (2014). Effect of total solid content to biogas production rate from vinasse. Int. J. Eng. 27 (2), 177-184. DOI: 10.5829/idosi.ije.2014.27.02b.02

Uni Bremen (2009). Biogas, Klärgas, Sumpfgas, Faulgas. Institute of Environmental Process Engineering of the Univesity of Bremen [online]. http://www.wasserwissen.de/abwasserlexikon/b/biogas 12/01/2018

VDI (2016). German norm VDI 4630. Fermentation of organic materials, characterisation of the substrate, sampling, collection of material data, fermentation tests. Verein Deutsche Ingenieure. Beuth editorial, November.

Ware A. and Power N. (2017). Modelling methane production kinetics of complex poultry slaughterhouse wastes using sigmoidal growth functions. Renew. Energ. 104, 50-59. DOI: 10.1016/j.renene.2016.11.045

Yangyang L., Yiying J., Hailong L., Aiduan B., Zhixin Y. and Jinhui L. (2018). Kinetic studies on organic degradation and its impacts on improving methane production during anaerobic digestion of food waste. Appl. Energ. 213, 136-147. DOI: 10.1016/j.apenergy.2018.01.033

Zhou Y., Zhang Z., Nakamoto T., Li Y., Yang Y., Utsumi M. and Sugiura N. (2011). Influence of substrate-toinoculum ratio on the batch anaerobic digestion of bean curd refuse-okara under mesophilic conditions. Biomass Bioenerg. 35 (7), 3251-3256. DOI: 10.1016/j.biombioe.2011.04.002

Zwietering M.H., Jongenburger I., Rombouts F.M. and Van't Riet K. (1990). Modeling of the bacterial growth curve. Appl. Environ. Microbiol. 56 (6), 1875-1881. 